\title{
Correction to: Long non-coding RNA H19 regulates FOXM1 expression by competitively binding endogenous miR-342-3p in gallbladder cancer
}

\author{
Shou-Hua Wang ${ }^{1 \dagger}$, Fei Ma ${ }^{2 \dagger}$, Zhao-hui Tang ${ }^{1 \dagger}$, Xiao-Cai Wu' ${ }^{1}$, Qiang Cai ${ }^{1}$, Ming-Di Zhang ${ }^{1}$, Ming-Zhe Weng ${ }^{1}$, \\ Di Zhou', Jian-Dong Wang ${ }^{1 *}$ and Zhi-Wei Quan ${ }^{1 *}$
}

\section{Correction to: J Exp Clin Cancer Res 35, 109 (2016)} https://doi.org/10.1186/s13046-016-0436-6

Following publication of the original article [1], the authors identified a minor error in Fig. 5; specifically:

- In Fig. 5a, an incorrect image was used for the si-NC group; the image has been replaced by the correct image.

The corrected figure is provided here. The correction does not have any effect on the results or conclusions of the paper.

\section{Author details}

${ }^{1}$ Department of General Surgery, Xinhua Hospital, Shanghai Jiao tong University School of Medicine, 1665 Kong Jiang Road, Shanghai 200000, China. ${ }^{2}$ Department of Oncology, Xinhua Hospital Affiliated to Shanghai Jiao tong University School of Medicine, Shanghai 200092, China.
Published online: 09 February 2022

\section{Reference}

1. Wang SH, Ma F, Tang Z, et al. Long non-coding RNA H19 regulates FOXM1 expression by competitively binding endogenous miR-342-3p in gallbladder cancer. J Exp Clin Cancer Res. 2016;35:160 https://doi.org/10. 1186/s13046-016-0436-6.

The original article can be found online at https://doi.org/10.1186/s13046016-0436-6.

*Correspondence: wangjiandong228@sina.com; Quanzhiwei3@163.com

†Shou-Hua Wang, Fei Ma and Zhao-hui Tang contributed equally to this work.

${ }^{1}$ Department of General Surgery, Xinhua Hospital, Shanghai Jiao tong

University School of Medicine, 1665 Kong Jiang Road, Shanghai 200000,

China

Full list of author information is available at the end of the article

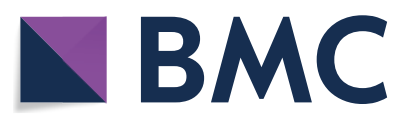

(c) The Author(s) 2022. Open Access This article is licensed under a Creative Commons Attribution 4.0 International License, which permits use, sharing, adaptation, distribution and reproduction in any medium or format, as long as you give appropriate credit to the original author(s) and the source, provide a link to the Creative Commons licence, and indicate if changes were made. The images or other third party material in this article are included in the article's Creative Commons licence, unless indicated otherwise in a credit line to the material. If material is not included in the article's Creative Commons licence and your intended use is not permitted by statutory regulation or exceeds the permitted use, you will need to obtain permission directly from the copyright holder. To view a copy of this licence, visit http://creativecommons.org/licenses/by/4.0/. The Creative Commons Public Domain Dedication waiver (http://creativecommons.org/publicdomain/zero/1.0/) applies to the data made available in this article, unless otherwise stated in a credit line to the data. 


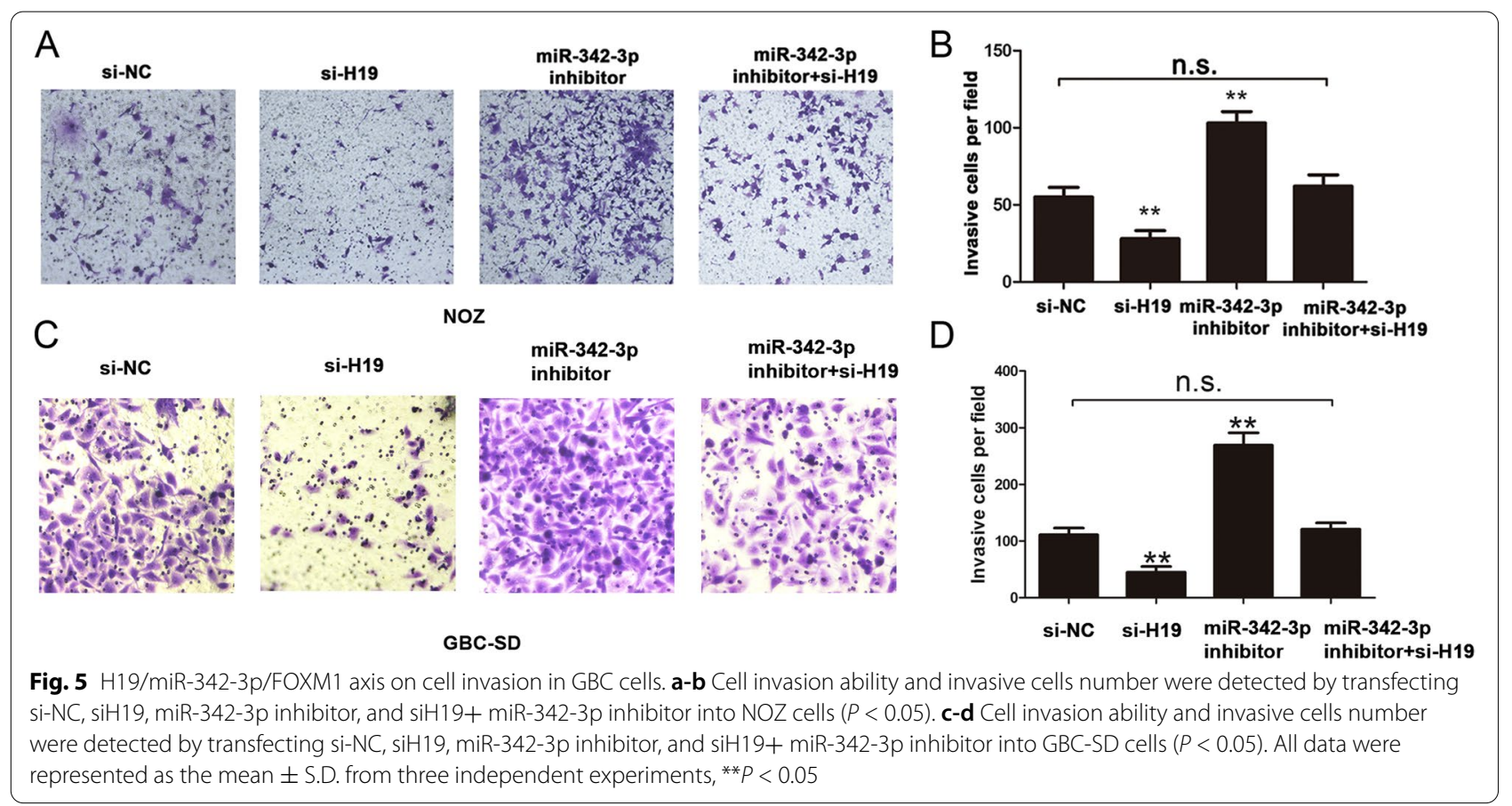

